\title{
THE BELFAST LABOUR DISPUTE AND RIOTS OF 1907
}

Almost all studies of industrial unrest in Britain before the First World War neglect the Belfast dock strike of 1907.1 Yet throughout the summer of 1907 that city was convulsed by a bitter and protracted strike involving dock labourers, carters and coal carters. At its height the dispute was estimated to have involved 10,000 on strike or locked out as a consequence of the strike, and threatened to involve a further 50,000 workers employed in the flax-spinning industry. In addition the strains which it imposed on the Belfast Royal Irish Constabulary precipitated a mutiny within that force, which induced the Liberal Government to sanction the despatch of some 6,000 regular soldiers to Belfast to maintain order.

In the context of the pre-war British political scene the Belfast strike was significant for a number of reasons. It was the first major industrial dispute to follow the passage of the Trades Disputes Act in 1906, and consequently illustrated some of the problems involved in the definition of peaceful picketing. The strike was also characterised by the rather confused syndicalism, personified in its leader Jim Larkin and evident in the use of the sympathetic strike, which exerted a strong influence on British trade unions between 1911 and 1914. In more immediate terms the Belfast strike was closely linked to the industrial conflict emerging on the British mainland between the Amalgamated Society of Railway Servants and the railway companies.

Yet probably the most interesting and important aspect of the strike was the widely held view that it heralded a potential realignment in

${ }^{1}$ For example H. Pelling, British Trade Unions (Harmondsworth, 1971), does not mention the strike, while H. A. Clegg, A. Fox and A. F. Thompson, A History of British Trade Unions since 1889, I : 1889-1910 (Oxford, 1964), only provide a brief comment. The best accounts are contained in E. Larkin, James Larkin (London, 1965), and J. D. Clarkson, Labour and Nationalism in Ireland (New York, 1925), but both rely almost entirely on two Ulster newspapers, The Irish News and the Northern Whig, respectively. 
working-class politics in Belfast. The fact that the strikers included both Catholics and Protestants was seen as a significant development, not only by Labourites and Socialists, but by The Manchester Guardian, which declared: "The strike itself, was not a commonplace one. It was, we believe, the first strike in the history of modern Ireland in which the workers forgot their party divisions and combined [...] against their employers."1 The prospect, then, that the strike would initiate an emerging working-class consciousness, which would transcend the traditional sectarian divide, provided the dispute with a wider significance and contemporary relevance. What follows is an account of the strike and an evaluation of its impact both on British politics and on the particular politics of Ulster before 1914.

On January 20,1907, James Larkin arrived in Belfast as an organiser for the National Union of Dock Labourers. The prevalence of low wages and poor working conditions in the Belfast docks enabled Larkin to recruit some 400 dockers for the union within three weeks of his arrival. By March the Glasgow ILP weekly Forward reported: "The newly-formed Dock Labourers Union is already making its presence felt and a crisis is rapidly approaching unless some of the more pressing disabilities are removed - low pay, hanging around for pay, [...] scanty meal allowance, money which is expected to be spent in certain licensed premises."'2 The crisis arose, somewhat unexpectedly, in May, when members of the union working for the Belfast Steamship Company refused to continue working alongside two non-union labourers. The union immediately repudiated the men's action as mistaken and instructed them to return to work. But the Company Chairman, Thomas Gallaher, concerned at the growing power of the union, saw the dispute as "the opportunity he desired to smash the newly formed Union, and the Shipping Federation were entrusted with the job of smashing it". ${ }^{3}$

The strikers were locked out and the struggle began. It would appear that the desire of the Belfast dockers' union to avoid a serious confrontation with the Belfast Steamship Company, at this juncture, was a function of its financial limitations. Although Larkin could claim a membership in excess of 3,000 men, the branch had not built up a financial reserve to fight a drawn-out strike, and, under the rules of the NUDL, was not entitled to claim benefit from the parent body until the branch had sustained itself for a year. Certainly Larkin saw the Steamship Company's action as a premeditated attack on his men, and as evidence produced a letter signed by the Secretary of the Shipping

1 The Manchester Guardian, August 16, 1907.

2 Forward (Glasgow), March 9, 1907.

3 Ibid., June 1. 
Federation and sent to their Belfast Office, which declared: "As you appear to anticipate a local dispute, we are sending through on Monday Mr. Levine, our general labour superintendent, who will thoroughly investigate the position, and we shall then be prepared to act immediately should the necessity arise."1

The immediate action taken by the Shipping Federation, on behalf of the steamship company, was to import "blackleg" labour. Following the initial dispute some 50 labourers were used to replace the union men, and by the middle of May a further 100 blacklegs were introduced. ${ }^{2}$ The use of blackleg workers raised the temperature of the strike and provoked the strikers to violence in the form of stone throwing directed at the blacklegs. At the end of May tension increased further when Larkin was arrested for striking a blackleg worker, Richard Bamber, with a shovel after Bamber had brandished a knife. Larkin was released on bail and finally acquitted after the trial had been postponed until January 1908.

About the same time as Larkin's arrest the NUDL leader, James Sexton, came to Belfast to appraise himself of the situation. Sexton described Gallaher as suffering from "Larkinitis", ${ }^{3}$ a disease later contracted by Sexton, ${ }^{4}$ and following his visit the NUDL agreed to support the Belfast branch with finance which Sexton later estimated to have cost the NUDL $£ 7,000 .^{5}$ As the strike progressed Sexton became increasingly alarmed at the financial cost involved and at the uncompromising determination of Larkin to continue the struggle to the bitter end. Sexton began to emerge as an important advocate of a compromise solution and was to play an influential role in bringing the strike to an end.

In the latter half of June the dispute assumed a wider significance when the union approached ten companies engaged in cross-channel operations for recognition of the union's negotiating rights and immediate improvements in pay and working conditions. Seven of those approached proved reasonable and agreed to settle, but the three large railway companies, the Lancashire and Yorkshire, London and NorthWestern and the Midland, refused even to recognise the union. ${ }^{6}$ The union's response was to call for the dispute to be settled by arbitration and suggested that the Lord Mayor of Belfast, the Earl of Shaftesbury,

1 The Irish News, May 9, 1907.

2 Forward, May 18, 1907.

Ibid., June 1.

- Cf. Sir J. Sexton, Sir James Sexton, Agitator: An Autobiography (London, 1936), pp. 201-08.

5 Cf. H. A. Clegg, A. Fox and A. F. Thompson, op. cit., p. 451.

- Labour Leader, July 5, 1907. 
act as the arbiter. The companies refused to consent to arbitration and replaced the striking cross-channel labourers with more blacklegs. The ILP weekly Labour Leader commented: "The fight is to continue, and on both sides there is the fixed determination to make it a fight to a finish."'1

The powerful railway companies began to apply pressure on local employers to institute lock-outs, and the Unionist press sought to divide the strikers by describing Larkin as an agent of the Pope. However, the strikers remained united and picketed the dock area in force. The authorities, alarmed at the prospect of violent clashes between pickets and blackleg labourers, used police to protect the blacklegs and detailed 500 soldiers to cordon off the quays from the strikers. The use of soldiers in this role developed as a factor in the strike itself, and in the general political controversy and debate associated with the strike.

On 27 June the Chief Secretary for Ireland, Augustine Birrell, was questioned in Parliament by Ramsay MacDonald, and answered that the military were employed in Belfast at the request of the Lord Mayor and as a result of information supplied by the civil authorities. ${ }^{2}$ Four days later he was again questioned, this time by the Labour MP David Shackleton, who wanted to know if troops had been attacked by strikers and, if not, why they could not be withdrawn. Birrell agreed that no violence had been directed towards the troops, but refused to allow their withdrawal arguing that their presence was necessary for the preservation of peace. ${ }^{3}$ The same day, the Nationalist MP for West Belfast, Joe Devlin, made a brief intervention in the dispute advocating the despatch of a special Government representative to Belfast to bring the strike to an end. Birrell outlined the Government's attitude by stating his hope for a quick settlement, but adding: "it would be foolish for me to interfere on a matter in which I have no locus standi."4

In fact James Larkin anticipated a rapid and successful conclusion to the dispute. In early July the railway companies' hopes of crushing the strike were seriously upset by the decision of a large number of carters to come out on strike for improved conditions and in sympathy with the dock labourers. One consequence of this decision was Larkin's success in recruiting the bulk of the striking carters. Another was the difficulty facing employers in trying to use blackleg workers to transport goods around a largely unknown and hostile city. Larkin was convinced that the railway companies were beaten and would agree to

1 Ibid., July 12.

House of Commons Debates, Fourth Series, Vol. 177, cc. 112-13.

Cf. ibid., cc. 373-74.

Ibid., c. 1174. 
arbitration. ${ }^{1}$ In fact he was mistaken and it was an error which reflected a lack of appreciation of the wider issues involved in the Belfast dispute for the railway companies.

From the perspective of the railway companies the principle involved in recognising and treating with the dockers' union had to be balanced against their impending struggle with the Amalgamated Society of Railway Servants. ${ }^{2}$ In 1906 the railway companies were presented with a series of demands from the ASRS to improve working conditions and increase wages. The railway companies were determined to resist these demands and indeed refused to meet a deputation from the railwaymen. It was widely anticipated that 1907 would witness an intensification of the struggle, and in seeking to crush the Belfast strike the companies were serving notice of their intentions towards the more powerful ASRS.

The Labour Leader was aware of the companies' aim and anxious that the trade-union movement should recognise the real issues at stake in Belfast. The Labour Leader reported: "The English railway companies $[\ldots]$ make no secret of their intention to prolong the struggle in order to make it an object lesson to Trade Unions in general and the Amalgamated Society of Railway Servants in particular. The result of this fight will largely determine the companies' attitude towards the railwaymen." 3 In the circumstances it was ironic that of 160 handpicked railwaymen used by the companies to break the strike more than 30 were found to be members of the ASRS. ${ }^{4}$

In early July the dock labourers and carters were maintaining a grim unity in the face of pressure and propaganda forthcoming from the employers and the Unionist Party press. The main thrust of the propaganda was directed at the Protestant elements, who formed the majority of strikers, and took the form of an accusation that the leadership of Larkin was designed to further the cause of Home Rule. To avert a possible crisis within the strike movement Larkin expressed his willingness to stand down from the leadership, and on 3 July The Belfast News Letter reported that Larkin had in fact resigned. The following day it was reported that a large meeting of strikers was told by the noted Protestant trade unionist, Alexander Boyd, that Larkin was to remain as leader: "There has been a deliberate attempt to work on party feeling on the eve of the Twelfth of July Celebrations [...]. Fortunately they had failed absolutely in their object, and the men of

1 Labour Leader, July 5, 1907.

2 For an account of the ASRS's struggle with the railway companies in 1906-07 cf. P. S. Bagwell, The Railwaymen (London, 1963), pp. 262-73.

- Labour Leader, July 12, 1907.

Ibid. 
both faiths $[\ldots]$ were determined to stand together against the common enemy, the employer who denied the right of the workers to a fair wage."' Larkin was greeted with enthusiasm by the meeting, and his position as leader remained secure throughout the potentially difficult days around the Twelfth of July.

Almost all accounts of the strike centre on the strength of the Catholic-Protestant working-class alliance and the challenge it offered to the political hegemony of the Unionist Party. Certainly the period of 1906-07 represented a crisis point for the Unionist Party, particularly with regard to its relations with Protestant workers. By 1906 a rival to the influential Orange Order had emerged within the Protestant working-class community, in the form of an Independent Orange Order. This body reflected an attempt by working-class Protestants to provide an alternative channel of influence for those who desired to maintain the union with Britain but doubted the willingness of the Unionist Party to represent working-class interests. ${ }^{2}$ Indeed the total absence of interest in the needs of the workers was evident in the failure of Unionist MPs to raise the issue of the Belfast strike in Parliament until the riots in August.

Although the IOO began as a narrowly sectarian body, the influence of one of its leaders and main "theoretician", Lindsay Crawford, led it to develop an orientation towards labour issues, which brought it into contact with the embryonic labour movement and the Catholic working class. At the same time the Nationalist Party, under Joe Devlin, developed a powerful organisation in West Belfast, which served as base from which the Nationalists could challenge the Unionist Party. The 1906 General Election afforded an opportunity for a very tentative, implicit electoral alliance to be operated by the IOO, Labour and the Nationalists against the Unionists in Belfast. As a result the Independent Unionist T. H. Sloan and the Nationalist Joe Devlin won South and West Belfast respectively, while William Walker came within 300 votes of capturing Belfast North for Labour.

An historian of the Unionist Party, Patrick Buckland, suggests that the Party was "struggling in face of this new threefold combination which showed signs of growing firmer by the time of the Belfast strike in $1907^{\prime \prime}{ }^{3}$ This seems to over-estimate the challenge to the Unionist

1 The Belfast News Letter, July 12, 1907.

2 For an account of the IOO cf. J. W. Boyle, "The Belfast Protestant Association and the Independent Orange Order, 1901-10", in: Irish Historical Studies, XIII (1962-63), pp. 117-52.

3 P. Buckland, Ulster Unionism and the Origins of Northern Ireland 1886-1922

(Dublin, 1973), p. 30. 
Party since anti-unionists fared badly at the Belfast Municipal Elections in January 1907.1 Moreover, a by-election held in North Belfast in spring 1907 saw the Unionist majority over the Labour candidate, Walker, increase to almost 1,500 votes. ${ }^{2}$ Indeed Budge and O'Leary, in their study of Belfast politics, assert: "By 1907, therefore, the Belfast Conservatives had beaten off a challenge from the growing Labour movement and had managed to contain the Catholic/Nationalists within their two carefully constructed wards."3

However, the attitude of the IOO to the strike was avowedly sympathetic in contrast to the Orange Order, which steadfastly sought to ignore its existence. As the Twelfth of July approached, the IOO argued that collections should be taken up for the strikers at all the great Orange processions, but the leadership of the Orange Order "declined to identify themselves in any way with the dispute".4 While the speeches made at the main Orange Order meeting on the Twelfth contained no reference to the strike, the IOO speakers expressed solidarity with the strikers and took up a collection at their meeting. Alexander Boyd and Lindsay Crawford were greeted with applause at the IOO gathering when they denounced the Unionist Party and "Old Orangeism" for their indifference to the problems of the working classes and opposition to trade-union principles. Lindsay Crawford was particularly scathing in his attack on the Orange Order, claiming "the old Orange bottle could not hold the new wine of twentieth century democracy [...]. The old order was the last bastion of class rule in Ireland and the open foe of the people [...]. The dust-bin of the Carlton Club and the tool of place hunting lawyers."'5

In the week before the Twelfth it appeared that a possible strike by the strategically important coal carters was going to be averted when it was reported that the coal merchants were prepared to meet the men's demands for more money, improved conditions and recognition of

1 Cf. Forward, January 26, 1907.

2 Belfast North was fought three times in successive years with the following results:

By-Election 1905

Sir D. Dixon 4440

William Walker 3966

Majority

474

3 I. Budge and $C$

Somewhat surprisingly, this study almost totally ignores the dock strike and even suggests that it was engineered by James Connolly, who was, in fact, in America at the time.

4he Belfast News Letter, July 11, 1907.

s Ibid., July 13. 
their union. Then in an about face the coal merchants withdrew their offer and issued a manifesto, which declared:

"We have unanimously decided - (1) That no person representing any Union or combination will be recognised by any of us; (2) that we will excercise our right to employ and dismiss whom we choose, and that all persons while employed by us shall work together harmoniously; (3) that in the event of a strike, whether general or confined to one or more firms, taking place due to dissatisfaction with the terms or conditions of employment prevailing in the trade, without at least three days' written notice having been given by the men to the employers, specifying the grievances complained of, we will immediately lock out all our men."1

It was generally believed that the "hard line" adopted by the coal merchants was the result of intense pressure applied by the railway companies.

However, on 12 July The Irish News reported that a mass meeting of the coal carters unanimously rejected the merchants' manifesto. The struggle was widening into a general battle for trade unionism. The result was that in mid-July approximately 1,000 coalmen were locked out by the Coal Merchants Association and the supply of coal to Belfast and the surrounding towns effectively ceased. The lock-out of the coal carters was the most serious escalation in the Belfast dispute since it threatened the main source of industrial power to the flax-spinning industry and consequently threatened the jobs of 50,000 to 60,000 workers. ${ }^{2}$

To prevent hardship to working-class domestic users the Belfast Cooperative Society ordered large shipments of coal, but it found difficulty in actually obtaining supplies due to the influence of the railway companies. $^{3}$ By the middle of July the lines between the striking dockers, carters and coal carters and the employers, headed by the three railway companies and the Belfast Steamship Company, were tightly drawn. The Co-operative Neres felt that never "in the history of trade unionism in Belfast, has so fierce a contest been waged between capital and labour as the one now existing between the carters and dockers of Belfast and their employers [...]. The approaches to the docks are guarded by large forces of military and police and the whole place has the appearance of an armed camp."4

1 The text was printed in Labour Leader, July 19, 1907.

a Cf. The Manchester Guardian, August 24, 1907.

3 Labour Leader, July 19, 1907, cf. The Co-operative News, July 27, 1907.

4 The Co-operative News, ibid. 
The possibility of violent clashes between strikers and police was increased by the widespread uncertainty over the definition to be applied to the concept of peaceful picketing authorised under the Trades Disputes Act. Union leaders argued that the action of police and military in protecting blackleg dockers and directing blackleg carters around Belfast was a breach of the strikers' right to picket and evidence of collusion with employers. The civil authorities were concerned to argue that withdrawal of police and military from the strike-affected areas would signal an outburst of violence against the imported workers. In the event the use of police as escorts in the transportation of goods around the city provoked frequent and violent clashes between strikers and the Royal Irish Constabulary. Moreover, the fact that the strike involved the police in long hours of potentially dangerous overtime, for which they received no extra payment, lowered the morale of a force already dissatisfied with pay and promotion prospects.

On 24 July a meeting of policemen was held in Musgrave Street barracks and addressed by Constable Barrett, who had earlier been temporarily suspended for refusing to act as a guide and guard for blackleg carters. The meeting was interrupted by Acting-Assistant Commissioner of Police Morrell, who declared the proceedings to be illegal and attempted to arrest Barrett. At this point the lights in the room were turned off and Morrell was struck falling "to the ground like a stunned bullock". ${ }^{1}$ An immediate crisis was averted by Morrell's plea to the men to suspend their action, and unsuccessful attempts were made to deny that any divisions existed within the Belfast RIC. However, Barrett informed The Irish Neres of the events and, on 27 July, led a march of more than 600 policemen through Belfast in a public parade of disaffection. ${ }^{2}$ In the course of the meeting which followed the policemen threw open the gates of their barracks to admit the strikers, and appeared ready to destroy the barracks and join forces with the carters and dockers in an attack on the docks.

Ironically, a genuine mutiny was avoided as a result of the advice given to the mass demonstration of police, dockers and carters by leaders of the strike committee. Larkin advised the strikers to leave the barracks and allow the policemen to formulate their grievances while maintaining their normal duties. As a result the policemen resolved to continue work but demanded the right to combine; an increase of one shilling a day; payment for overtime and improved pensions. If these demands were not met by 3 August the protesting policemen declared their intention to strike. ${ }^{3}$ Ominously for the authorities, Barrett told

1 The Irish News, July 25, 1907.

The Manchester Guardian, July 29, 1907.

The Irish News, July 29, 1907. 
his followers that he had numerous telegrams of encouragement and support from RIC men throughout Ireland. But the Government acted swiftly to crush the incipient mutiny and, in response to appeals from the Lord Mayor of Belfast, more than 6,000 regular troops were despatched to the city. On 30 July the 1st Battalion Cameronian Highlanders and the 1st Berkshire Regiment entered Belfast, and on $5 \mathrm{Au}-$ gust a Times editorial announced that 7,000 troops and maxim guns were deployed in the city to maintain order since "the mutinous element in the Constabulary has hastened to identify itself conspicuously with the cause of the strikers".

The dramatic events concerning the RIC tended to deflect attention away from the more significant change in the position of the coal carters. Their involvement in the industrial struggle held the key to its general outcome. With supplies of coal growing scarcer the main source of fuel to Belfast's industrial and commercial prosperity was threatened. This situation prompted the employers to seek a compromise settlement which would remove the threat to wider capitalist interests, and fundamentally weaken the ability of the dockers and carters to win the strike in the docks. On 26 July the coal carters, represented by James Sexton and Alexander Boyd, agreed to return to work on the terms obtaining six weeks previously. In effect the coal merchants agreed to simply rescind their lock-out and the dispute was formally concluded. ${ }^{1}$

The Labour Leader expressed surprise that the men did not hold out for better terms, ${ }^{2}$ but the agreement of 26 July appeared increasingly unstable as the coal carters experienced the operation of its terms. The most important grievance felt by the men concerned the refusal of some employers to take on the same firms of carters as before the dispute, and it was clear that a further conflict was inevitable. ${ }^{3}$ Despite difficulties with the coal carters' settlement Sexton believed that such an agreement offered the best opportunity for an end to the dockers' and carters' dispute still directly involving over 1,000 men. Larkin was opposed to such a capitulation, and saw the coal settlement as evidence of equivocation and weakness on the part of Sexton. In the final anallysis any agreed settlement was impossible given the determination of the railway companies to achieve a complete victory. Indeed the conclusion of the coal strike must have strengthened that resolve.

The persistence of violent clashes between strikers and the police and military, followed by the massive military intervention, brought the Belfast strike to the attention of the national news media. On $10 \mathrm{Au}-$ gust The Spectator, echoing the position of The Times, supported the

The Manchester Guardian, August 22, 1907.

${ }^{2}$ Labour Leader, July 19, 1907.

3 The Manchester Guardian, ibid. 
use of troops and anticipated an end to the disturbances: "The existence of organised violence in the neighbourhood of the docks has been proved to demonstration, and we do not doubt that the Government will make an end of it." The association of violence with the strikers was fostered by the Unionist MP for North Armagh, W. Moore, who told Parliament that the "peaceful picketers are all armed with heavy bludgeons". 1 But not all opinion was confident that the use of troops was justified. The Liberal weekly The Nation felt there to be a contradiction in using troops in support of railway companies which consistently rejected the offer of the strikers to go to arbitration. The $\mathrm{Na}$ tion urged that "the attention of the Government will be directed to the responsibility of the railway and shipping companies, for this state of anarchy". ${ }^{2}$ The New Age concentrated on the role of the Government, and the responsible Minister, Augustine Birrell: "Mr. Birrell is but following the precedent set by Mr. Asquith at Featherstone and his Tory successor at Bethesda in using the forces of the Crown to compel the Belfast strikers to submit to their masters. [...] the troops $[\ldots]$ are $[\ldots]$ the protectors of the capitalists and their blackleg lackeys." 3

Liberals were particularly sensitive to the charge that a Liberal Government was involved in coercing strikers by the use of troops. Yet support for this view came from the Liberal MP Leo Chiozza Money, who suggested that Birrell and the Government had surrendered to pressure from the Shipping Federation. Money claimed that the Federation had sent a letter to Birrell dated 25 July to the effect "that failing strong action by the Government they themselves would use force, that they would organise a force of their own". ${ }^{4}$ Birrell admitted that he had received such a letter, but denied that it influenced the Government into sanctioning the use of troops in Belfast. Indeed, Birrell had earlier declared: "I have no power to remove the military from Belfast if the civil authorities wish them to remain there."' It was later argued by Government spokesmen that since local authorities were legally responsible for the maintenance of law and order in their areas, Government was obliged to render such assistance as was requested by the Belfast authorities. ${ }^{6}$

Although the Labour press was concerned about the role of the mili-

1 House of Commons Debates, Vol. 180, c. 349.

2 The Nation, August 3, 1907.

3 The New Age, An Independent Socialist Review of Politics, Literature, and Art, August 8, 1907.

4 House of Commons Debates, ibid., c. 1071.

5 Ibid., c. 349.

- Cf. ibid., cc. 346-50. 
tary in the industrial dispute, it was encouraged by the solidarity of the strikers, which survived the potentially divisive events of the 12 July Protestant celebrations. The Clarion shared the view expressed in The New Age that "the really hopeful feature about the whole affair is the cordiality with which Orange and Nationalist Labourer appear to be working together in defence of their common interests and rights". 1 The Scottish Labourite J. O'Connor-Kessack was present in Belfast for the Orange celebrations on 12 July, and was heartened by the lack of violent, sectarian demonstrations and acrimony. As a consequence he believed that "there are signs enough of a great working-class awakening in Belfast". ${ }^{2}$ In the same issue of Forward, H. R. Stockman went further in anticipating that the strike was an event "which threatens to engulf the whole north of Ireland and to alter the whole Industrial, Economic and Religious Outlook of the Workers". ${ }^{3}$ The fact that Larkin could address enthusiastic meetings on the Protestant Shankhill Road, while Boyd, Crawford and Walker were warmly cheered on the Falls Road, was a significant advance which appeared to herald a more fundamental change in the outlook of the Belfast workers.

However, by early August events began to quicken. The police mutiny was effectively crushed with the dismissal of Barrett and a number of other constables and the transfer of some 253 Belfast police to the rural parts of Ireland. ${ }^{4}$ In their place the authorities drafted replacement police unused to the complex problems of Belfast in the throes of a strike. The fact that these reinforcements were stationed in the Catholic areas alongside the bulk of the military force served to increase a sense of impending conflict. Frequent, if minor, incidents occurred between the military and the local Catholic-Nationalist population, who viewed the forces of law and order as a provocation by a hostile and foreign Government. The Irish News argued that a serious confrontation was inevitable, ${ }^{5}$ and the Belfast Nationalist leader Joe Devlin was forced to abandon his stance of studied ambivalence towards the strike. On 11 August Devlin appeared on a public platform with Larkin and Crawford. The gathering appeared to personify the synthesis of the alliance between the Nationalists, the IOO, and Labour begun the previous year. Devlin explained his earlier silence on the strike by stating that he was concerned to avoid providing the

1 The New Age, August 1, 1907; also The Clarion, July 12, 1907, and Labour Leader, July 19, 1907.

2 Forward, July 27, 1907.

${ }^{3}$ Ibid.

Labour Leader, August 9, 1907.

5 Cf. The Irish News, July 31, 1907. 
opportunity for the Unionist Party to attack the strike as part of some Nationalist intrigue. ${ }^{1}$

But this development in the course of the strike was immediately eclipsed by the fatal clashes between troops and demonstrators on the Falls Road over the week-end of 11 and 12 August. On Sunday 11 August police attempted to take into custody two drunken men on the Falls Road and were almost immediately attacked by a crowd demanding their release. Troops and police were rushed to the area and a violent confrontation followed, in which many participants were injured and others arrested. The following night saw renewed clashes between the local inhabitants and the strengthened contingent of troops and police, which lasted for several hours, during which time the Riot Act was read and the troops "not only repeatedly charged with bayonet, but were on more than one occasion obliged to use ball-cartridge".'2 As a result Charles Mullan, Charles Kelly and Margaret Lennon were killed and a larger number wounded. Several soldiers were taken to hospital suffering from cuts and bruises, but none were detained. ${ }^{3}$ The Nationalist newspaper, The Irish News, proclaimed the military action as "bloody murder"," and the incident was seen in the Catholic areas as the action of an oppressive army of occupation. Further violence was averted by the Lord Mayor's decision to withdraw the troops from the troubled areas, which followed representations by leading Catholic and Nationalist spokesmen.

The violent events provided Orange and Unionist leaders with an opportunity to disassociate themselves from the actions of the inhabitants of the Falls Road and, more importantly, to characterise events as part of Nationalist aggression. Loyal Protestants were supposed to beware of contacts with Catholics, and the Grand Master of the Belfast Orange Order issued an appeal to "every member of the loyal Orange institution to himself keep away from the area of disturbance, and also use his influence on others to do the same, so that under no pretext whatever can it be alleged that at any time our people had either hand or part in it".5 The desire to show that "our people" were not involved was shared by T. H. Sloan, Independent Unionist MP for Belfast South, who suggested that the violence was occasioned by "Nationalists" and "won't workers". 'It is important to remember that Sloan was a leading member of the $\mathrm{IOO}$ and that he, more than any

1 Ibid., August 12.

The Spectator, August 17, 1907.

The Times, August 14, 1907.

- The Irish News, August 13, 1907.

5 The Times, August 15, 1907.

- House of Commons Debates, ibid., c. 1666. 
other of its leaders, reflected the deep-rooted ambivalence about the wisdom of associating themselves with Home Rulers, whether it be Larkin or Devlin. In the aftermath of the strike, Sloan expressed reservations about its aggressive, even violent, nature, and while prepared to countenance common action on some issues with Catholics denied any intention "to blend Orange and Green". 1

While Unionists attempted to manipulate the August disturbances to divide the strikers, Larkin struggled to maintain unity. Following the riots he toured the Catholic areas, posting notices calling on the workers "to stand together, and don't be misled by the employers' game of dividing Catholic and Protestant". ${ }^{2}$ Yet the disturbances and deaths clearly did divide the workers, who tended to analyse the events in terms of support for Unionism or Home Rule. More immediately the riots were important in terms of their effect on British public opinion, the Liberal Government and the NUDL.

The shootings on the Falls Road took British public opinion by surprise and confused and divided opinion. On 14 August The Times published an editorial which strongly supported the actions of the military and laid the responsibility for the violence on Nationalist attackers. On the same day it also reported that "a very large attendance" at a meeting in Northampton passed a resolution denouncing "the employment of British soldiers to murder, in cold blood, defenceless working men and women". ${ }^{3}$ The Manchester Guardian was more troubled by the events in Belfast than The Times, and criticised the hypocrisy of the Orange Order in attacking Nationalists for the violent abuse of the forces of law and order when the Order had a history of such excesses. While The Manchester Guardian agreed that attacks on the military could not be tolerated it was concerned to ensure that "the general censure of the disorders should not obsure the fact that with the employers in this case rests the prima facie responsibility for preventing the dispute from being $[\ldots]$ settled". ${ }^{4}$

The attitude of the Parliamentary Labour Party was marked by uncertainty. Victor Grayson, the recently elected and avowedly socialist MP for Colne Valley, was the most outspoken Labourite. Grayson, who was not a member of the PLP, was uncompromising in his support for the strikers and in his view that the military action was an exercise in class politics and power..$^{5}$ But in the main Labour members were subdued in

1 Cf. J. W. Boyle, loc. cit., p. 149.

2 The Times, August 15, 1907.

3 The Manchester Guardian reported a similar resolution from the Bury Trades Council on August 31.

- The Manchester Guardian, August 13.

5 Cf. ibid., August 12 and 14. 
their comments, and generally sought to separate the question of responsibility for the sending of troops to Belfast in the first place from that of responsibility for the actual loss of life. Philip Snowden expressed regret that troops had been used to maintain order during an industrial dispute, but accepted the view that there were circumstances when "the civil authorities must take all the steps which they may consider necessary to ensure the public peace". ${ }^{1}$ This view was endorsed by Robert Blatchford, who condemned the Belfast attacks on the "ordinary Tommy". ${ }^{2}$ But both were condemned by the SDF journal, Justice. ${ }^{3}$ Labour spokesmen found it difficult to raise the shootings in Parliament due to procedural problems, but Pete Curran, recently elected Labour member for Jarrow, managed to raise the issue during the passage of the Consolidated Fund (Appropriations) Bill. However, Curran's contribution was low-key, and reflected Labour's determination to assure all concerned that it neither supported nor encouraged the use of violence against the legally constituted forces of law and order. His criticism took the form of an appeal to the Government of "the necessity of exhausting every other means before the military were allowed to enter any town or city where an industrial dispute was taking place". "In reply Birrell assured the Labour members that the Government knew they did not countenance violence and thanked them for their assistance. ${ }^{5}$

The response of the labour movement outside Parliament was more hostile. Indeed the SLP monthly, The Socialist, was unable to restrain itself in the light of Labour's ineffectual Parliamentary performance. It denounced "the shameless and never-to-be-forgotten treachery of the Labour Party from Will Thorne downwards on the occasion when the massacre of the Falls district came up in Parliament and every 'labourist' played the part of a dumb, unprotesting accomplice in capitalist butchery". ${ }^{6}$ Justice concentrated its attention on the culpability of the Liberal Government in what it described as "Another Asquithian Crime". Birrell was likened to Asquith, who was held to be responsible for the fatal shootings during a strike at Featherstone in $1893 .{ }^{7}$ In an editorial Justice reported that the army commander in Belfast, General Dawson, had toured the troubled areas on the Saturday previous to the

1 The Scottish Co-operator, August 23,1907.

2 The Clarion, August 16, 1907.

3 Justice, August 24, 1907.

4 House of Commons Debates, ibid., cc. 1660-61.

5 Ibid., c. 1675.

- The Socialist, October 1907.

7 Justice, August 17, 1907. The New Age, August 15, wrote of "Russian methods of government" and said Belfast "was turned into an Irish Warsaw". 
violence "and hinted that should there be a renewal of serious disturbances [...] they [troops] will not hesitate to fire". ${ }^{1}$ The revolutionary socialist John Maclean had been in Belfast just before the shootings and had been impressed by the workers' tremendous enthusiasm for trade unionism. In the aftermath of the deaths he maintained: "It is our duty to proclaim the Belfast Council immediately responsible for the murder of innocent members of our class, and the Liberal Government ultimately responsible for the infamous deed."'2

Criticism was not confined entirely to the more extreme socialist press. The Liberal journal The Nation had been concerned at the intransigent attitude of the railway companies and was convinced that the violence was a consequence of bad labour conditions amongst unskilled workers in Belfast. It argued that "the authorities were certainly associated closely with the great employers of labour, and they in turn had refused arbitration, refused recognition of the men's authorised representatives". In such a situation The Nation asked: "Has the party which refuses peace the right to demand of the State the means to carry on war, even to the bitter end of bullets?"3 Demonstrations condemning the actions of the Government took place throughout Britain during August, culminating in a large meeting at Battersea Park and a march through the East End of London, led by John Scurr, George Lansbury and Harry Quelch on 25 August. ${ }^{4}$

In the wake of the Belfast violence the Liberal Government and the NUDL determined to bring the strike to a speedy end and avert any further violent confrontations. The Government sent Birrell's undersecretary, Sir Antony MacDonnell, with George Askwith and Alderman Mitchell, to Belfast to negotiate a settlement. At the same time James Sexton, alarmed at both the cost of the strike and Larkin's leadership, assumed control of the dock labourers' negotiations from Larkin, who continued to act on behalf of the carters. After a series of meetings between the employers' representative McDowell, Government representatives MacDonnell, Askwith and Mitchell, and the strikers' negotiators, notably Sexton and Larkin, a provisional agreement was reached on 15 August. ${ }^{5}$

Larkin achieved wage increases and improved conditions for the carters, but the employers successfully resisted recognition of the men's union. The dock labourers achieved nothing directly in the way of wages and conditions, but were advised by Askwith that "their

1 Justice, ibid.

2 Ibid., August 24.

3 The Nation, August 17, 1907.

- The Times, August 26, 1907.

S Cf. The Manchester Guardian, August 27, 1907. 
course was to return to work, when they would certainly get a corresponding rise from employers who would do nothing while they were on strike". 1 But after studying the conditions contained in the settlement, the Times correspondent concluded: "A careful analysis of the terms agreed upon last night between the conflict parties shows unmistakably that the victory in the main lies with the masters."'2

On 24 August the terms were accepted at a mass meeting of the men addressed by Larkin, and to which Sexton went armed as a precaution against the possible reaction of dock labourers, who had endured the strike longest and were guaranteed nothing at its end. In fact there was general confusion as to the exact terms agreed and many dockers believed that they had won most of their objectives. Certainly Sexton claimed that the settlement was an honourable one, and justified his decision to waive the right of recognition for his union by the three railway companies, arguing that it was not the dockers' responsibility to fight the trade-union battle for the ASRS. ${ }^{3}$ Much later Larkin argued that the dockers had been misled at the mass meeting:

"The men voted to accept certain proposals but they never voted to accept what was set down in the statement which was that they were to work with non-union men. It was understood by the men that the strike was settled, and they were going back to work on the former conditions as to conditions of work, but the rates of wages would be gone into at a later date [...]. Afterwards the agreement was found to be of such a nature as no trade unionist could approve of [...]. The Lancashire and Yorkshire Company refused to take the men back at all under any conditions and 161 men were victimised. The Belfast strike eventually ended in disaster for the men, although in the beginning of the negotiations everything promised success." 4

Negotiations to settle the main strike were paralleled by the attempt to prevent the complete breakdown of the coal-carters agreement of mid-July. Following that agreement difficulties had arisen over its implementation and a second strike was widely anticipated. ${ }^{5}$ Indeed notices of a lock-out were given to more than 50,000 flax-spinning workers to be withdrawn if the coal dispute was satisfactorily settled. In fact after prolonged and exhaustive discussions it was agreed that the

1 Lord Askwith, Industrial Problems and Disputes (London, 1920), p. 112.

2 The Irish News, September 6, 1907.

3 Industrial Council, The Report on the Enquiry into Industrial Disputes [Cd 6952] (1913), p. 243.

Ibid., p. 247.

sf. The Manchester Guardian, August 24, 1907. 
coal merchants would retain the right to employ at their discretion, but they were subject to tighter controls over rates of pay and conditions of work. In addition a system of conciliation and arbitration was introduced to prevent any future crisis in the industry. ${ }^{1}$

The Belfast conflict represented a notable victory for capital over labour, most dramatically symbolished in the capitulation of the dockers employed by the Belfast Steamship Company. On 5 September the men who were involved at the start of the struggle were compelled to wait on the Company to express "their sorrow for what had happened, their earnest desire to return to work on the old terms, and their intention, if reinstated in their employment, of working harmoniously with any fellow employees"'.2 The defeat of the strike acted as a brake on the tendency towards the unionisation of unskilled labourers in Belfast. ${ }^{3}$ More importantly, it killed any prospect of a general working-class awakening in the city, and by 1910 the Belfast workers were effectively divided into opposed camps with the return to a politics dominated by the Home Rule issue.

Almost all explanations of why the workers' alliance of 1907 proved to be such a transitory phenomenon concentrate on the enduring strength of primary, traditional loyalties. Clearly those who anticipated a blending of Orange and Green labourers underestimated the tenacity of older loyalties and overestimated the strength of class feeling conspiring to break them down. It is difficult to appreciate how a coherent and united working-class movement could have emerged out of the strike experience, unless the strikers' movement was able to transcend its socalled allies, the Nationalists and the IOO. If labour was to effect such a transformation it was necessary to develop a policy on Home Rule. To say nothing on the issue, which was the position adopted by the strike leaders during the strike, may have been a necessary expedient in 1907, but it was an unsound strategy for the longer-term interests of the labour movement. It meant that the major and potentially most divisive political issue in Ulster remained in the hands of Unionist and Nationalist politicians. Devlin's hold on the Belfast Catholic working class remained secure as long as he monopolised the use of the Home Rule card. Likewise the IOO was an unreliable ally for labour since it was open to manipulation by the Carsons and Craigs of the Unionist Party. Moreover, the IOO had originated as a determined expression of radical sectarianism, an instinctive reaction to the dominance of middle- and upper-class interests in the Unionist Party, and not as a

1 Ibid., August 27.

2 The Irish News, September 5, 1907.

3 Industrial Council, op. cit., p. 246. 
coherent body of Socialist or trade-union opinion. The tendency to associate Lindsay Crawford's views with those of the rank and file of the IOO is misleading. Within a year of the Belfast strike Crawford was expelled from the IOO, and it was clear that the Order was uncertain and unsettled by the rapid change in its political orientation under Crawford and unhappy at its close association with Home Rulers. ${ }^{1}$

In an important sense it could be argued that Larkin's failure to translate the strike experience into a more permanent working-class movement was a failure of political direction. Larkin could have attempted to develop the idea of a socialist republic, and characterised both Nationalist and Unionist Parties as being primarily motivated by economic interests which were antipathetic to the interests of labour. Certainly it would appear that Connolly moved in that direction after the failure of the Dublin strike of 1912-13. But Belfast presented a more complex and difficult situation than Dublin.

In the final analysis such a fundamental change in political strategy required clear-sighted and determined leadership and a developing working-class consciousness based on a confident expectation of its industrial and political power. Larkin was able to provide determined leadership in the industrial sphere, but was unable to relate the industrial struggle to clearly perceived political objectives. ${ }^{2}$ More importantly the prospects for working-class advance in Belfast required a boost to the confidence and consciousness of the workers. The strike and the associated struggle raised consciousness and expectations among workers, but they were dashed in the general defeat which followed. Larkin drew the lesson that Sexton in particular, and British trade unions and the Labour Party in general, were unprepared to understand or wholly support the working-class struggle in Ireland. As a result Larkin and Connolly developed the Irish Transport and General Workers Union, and attempted the synthesis of syndicalism and nationalism as a programme of political action.

In conclusion, the Belfast strike can be seen to represent an important stage in the evolution of an independent Irish labour movement. But the fact that it was effectively defeated by Thomas Gallaher and the three railway companies was a serious blow to the development of a non-sectarian working class in Ulster. In Britain the strike was rapidly overtaken as a political event by the struggle between the railway companies and the ASRS which it foreshadowed. As in the case of Belfast the railway companies were able to resist recognition of the trade union involved, although the active intervention of Lloyd Greorge

1 J. W. Boyle, loc. cit., p. 150.

2 Cf. E. McCann, War in an Irish Town (Harmondsworth, 1974), p. 141. 
forced them to make concessions to the men. Whatever else, the Belfast strike did provide an important indication of the form the impending clash between resurgent new unionism and employers would take before the First World War. It also provided labour with one of its rare opportunities to shape the future course of Irish and Ulster society. The fact that it did not leave a lasting imprint on either should not obscure the important possibilities and problems which the strike raised, and which have a relevance for an understanding of the contemporary situation in working-class Belfast. 